\title{
Invasive species in Europe: ecology, status, and policy
}

Reuben P Keller ${ }^{1 *}$, Juergen Geist ${ }^{2 \dagger}$, Jonathan M Jeschke ${ }^{3 \dagger}$ and Ingolf Kühn ${ }^{4 \dagger}$

\begin{abstract}
Globalization of trade and travel has facilitated the spread of non-native species across the earth. A proportion of these species become established and cause serious environmental, economic, and human health impacts. These species are referred to as invasive, and are now recognized as one of the major drivers of biodiversity change across the globe. As a long-time centre for trade, Europe has seen the introduction and subsequent establishment of at least several thousand non-native species. These range in taxonomy from viruses and bacteria to fungi, plants, and animals. Although invasive species cause major negative impacts across all regions of Europe, they also offer scientists the opportunity to develop and test theory about how species enter and leave communities, how nonnative and native species interact with each other, and how different types of species affect ecosystem functions. For these reasons, there has been recent growth in the field of invasion biology as scientists work to understand the process of invasion, the changes that invasive species cause to their recipient ecosystems, and the ways that the problems of invasive species can be reduced. This review covers the process and drivers of species invasions in Europe, the socio-economic factors that make some regions particularly strongly invaded, and the ecological factors that make some species particularly invasive. We describe the impacts of invasive species in Europe, the difficulties involved in reducing these impacts, and explain the policy options currently being considered. We outline the reasons that invasive species create unique policy challenges, and suggest some rules of thumb for designing and implementing management programs. If new management programs are not enacted in Europe, it is inevitable that more invasive species will arrive, and that the total economic, environmental, and human health impacts from these species will continue to grow.
\end{abstract}

Keywords: Alien species, Biodiversity conservation, Biological invasions, Biotic resistance, Impacts of invasive species, Management, Pathways, Policy, Tens rule, Vectors

\section{Introduction}

Globalization has integrated widely dispersed human communities into a worldwide economy. This process provides many benefits through the movement of people and goods, but also leads to the intentional and unintentional transfer of organisms among ecosystems that were previously separate [1]. Some of these species become established beyond their native range, a subset of these spread, and some of these have negative impacts and are termed invasive [2]. Although not all species moved beyond their native range become established [3], the large number of species transported and the range of

\footnotetext{
* Correspondence: rpkeller@uchicago.edu

+ Contributed equally

'Program on the Global Environment, University of Chicago, Chicago IL 60637, USA

Full list of author information is available at the end of the article
}

pathways that move species mean that non-native species are now recognized as one of the major drivers of global biodiversity loss. They also cause significant damage to economies and human health [4-7].

Europe has been a centre for international trade for many centuries and has consequently seen the establishment of a large number of species. Some of these species have positive effects, including a subset of those introduced to enhance fisheries. Many other species, however, cause large negative impacts. These species cover a broad taxonomic range - from viruses and bacteria to fungi, plants, and animals - and affect all European nations and regions [6]. Where timelines are available, the number of non-native species established in Europe is generally increasing exponentially in freshwater [8] and terrestrial ecosystems [5,8-11]. This

\section{SpringerOpen ${ }^{\odot}$}


pattern is consistent with exponential increases in trade and travel [5]. Without increased efforts to manage pathways of introduction, the number of invasive species will continue to grow. Indeed, because there is often a significant lag period between species introduction and spread, it is likely that many future invasions have already been set in motion $[12,13]$. Consequently, the task of designing policies to reduce the transport and release of non-native species, and to manage those already established, has become a large priority for both national governments within Europe, and for the European Union $[14,15]$.

In contrast to their negative impacts, non-native species offer large opportunities for ecologists to test fundamental theory $[16,17]$. In many cases, established nonnative species spread rapidly into new ecosystems. These species interact with native species through competition, predation, herbivory, introduction of disease, and resource use. When carefully studied, the effects of these perturbations allow insight into basic ecological processes. For example, community ecology seeks to understand why certain species communities exist (or do not), and how species within those communities interact. Because invasions involve new species entering communities and interacting with resident species, they offer insight into these patterns and processes. The very real need to better understand the process of invasion so that native habitats can be conserved, combined with opportunities to test fundamental ecological processes, has led to huge recent growth in the field of invasion biology (e.g. [18]), including in Europe.

The goal of this paper is to review the ecology and current status of non-native species in Europe, and to outline a framework for policy to reduce their number and impacts. We begin with a description of the invasion process through which non-native species are introduced, become established, and may then go on to have negative impacts. This structures the sections that follow which cover the pathways of species introduction, the characteristics of habitats and species that lead to establishment, the number of non-native species in Europe, and their impacts. Finally, we describe some characteristics of species invasions that create unique challenges compared to other environmental issues. We propose some general principles to govern the policy response to the risks from invasive species. Throughout the paper, we discriminate among three groups of organisms: terrestrial animals, terrestrial plants, and aquatic organisms. This distinction corresponds to the published literature, which in many cases is quite divergent among the groups. Our sections about aquatic organisms include both marine and freshwater species. We primarily review material specific to species invasions in Europe, but include work conducted elsewhere as necessary.

\section{The invasion process}

To become invasive, a species must pass through a number of transitions (e.g. [2,19,20]). First, it must be entrained in a pathway and survive transit, where a pathway is a human-mediated process that facilitates the movement of species from one region to another. When it arrives in a region beyond its native range due to direct or indirect human intervention, it is referred to as introduced. Species that are not able to maintain selfsustaining populations, but that are occasionally found beyond cultivation, are often termed casual species. Next, if a species survives, escapes, and begins reproducing without direct human intervention it is referred to as established. Finally, we refer to a species as invasive if it spreads widely and causes measurable environmental, economic, or human health impacts.

Although the process described above is common to all invasions, different terminologies have been proposed, and these are often associated with different taxa or regions. For example, botanists may speak of an invasive plant as one that exceeds some predetermined rates of spread, whether or not it causes negative impacts (e. g. [19]). While we acknowledge the range of terminologies available, throughout this paper we use the definitions given in the previous paragraph.

The proportion of introduced species that become established can be quite low, as can the proportion of established species that spread and become invasive. These proportions vary with the taxonomy of the species in question, and the regions to which they are introduced. The 'tens rule' was proposed by Williamson [3] as a rule of thumb to approximate the proportion of species that make it through each step in the invasion process. This rule holds that approximately $10 \%$ of introduced species will become established, and approximately $10 \%$ of those species will become invasive. Hence, if 100 alien species were introduced, the tens rule holds that one will become invasive. The tens rule was developed with a focus on terrestrial plants, but has been applied by other authors to a wide range of species, often without thoroughly evaluating its validity. For example, recent studies show that for many animal taxa, the percentage of introduced species that become established and the percentage of established species that become invasive can exceed 50\% [5,21]. According to the definition of invasive given above, Europe now contains $>100$ terrestrial vertebrates, $>600$ terrestrial invertebrates, $>300$ terrestrial plants, and $>300$ aquatic species that have become invasive [7].

The following sections are organized to follow the invasion process. In each, we describe the current state of knowledge about non-native terrestrial animals, plants, and aquatic organisms in Europe. We discuss the dominant pathways of introduction and the characteristics of 
ecosystems and species that most often lead to establishment. Next, we give estimates of the number of established non-native species from each group in Europe, and describe their impacts.

\section{Introduction pathways}

There is a long history of classifying the pathways of non-native species. One of the oldest classifications was developed by Thellung [22,23] for Central Europe. More recent schemes are from [9] and [24], and reviews and syntheses are from [25] and [11]. Hulme et al. [9], the most recent classification from a European perspective, identified three general mechanisms through which non-native species may enter a new region: importation as or with a commodity, arrival with a transport vector, and dispersal by the species themselves, either along infrastructure corridors (e.g. roads, canals) or unaided. The first of these, transportation as or with a commodity, arises from direct human movement of goods. Transportation as a commodity occurs when people identify a species as having desirable qualities and intentionally move it beyond its native range. Species introduced as commodities can be released intentionally (e.g. stocking animals to create populations for fishing and hunting, introduction of species as biological control agents) or can escape unintentionally (e.g. ornamental plants reproduce and spread beyond gardens, fish in aquaculture facilities escape). Species transportation with a commodity occurs when traded organisms arrive contaminated by non-native species, including diseases and parasites. These contaminants are not introduced intentionally, but may escape to become established and invasive. For example, the crayfish plague disease (Aphamomyces astaci) was introduced to Europe on North American crayfish imported for aquaculture. This disease has escaped, become established, and now infests and endangers native crayfish populations across Europe [26]. Another example is the Asian tiger mosquito (Aedes albopictus), which is native to South-east Asia but has spread to at least 28 countries, including several European countries, on ships as a contaminant of the trade in used car tires [27].

The second mechanism, arrival with a transport vector, refers to species that hitchhike on human modes of transport to reach regions beyond their native range. Modes of transport include ships (e.g. species in ballast water or attached to hulls), airplanes (e.g. contaminants of cargo, diseases/pests on food carried by passengers), and automobiles (e.g. as seeds caught in mud on tires). The influence of ships has been particularly strong in aquatic ecosystems, with many marine and freshwater species having become harmful invaders after dispersal in or on ships [28]. In Europe, this has included the spread of zebra mussel (Dreissena polymorpha) from the
Ponto-Caspian Basin to the Atlantic and U.K. through the river and canal network.

The third mechanism is dispersal by the species themselves, either along infrastructure corridors or unaided. Corridor dispersal occurs when organisms move along canals, railways, roads, and other linear habitats created by humans. Examples include the introduction of species from the Red Sea into the Mediterranean Sea through the Suez Canal [29]. Unaided dispersal occurs when a non-native species becomes established in a neighbouring or nearby ecosystem, and then spreads without human intervention. An example is the continuing spread of invasive horse-chestnut leafminer moth (Camariella ohridella) [30] across Europe. Although this species was only introduced into a limited area, it has developed large populations and spread widely. Table 1 lists a number of important pathways that have transported species that are now established to Europe.

\section{Terrestrial animals}

Most terrestrial vertebrate animals established in Europe (or elsewhere throughout the world) were intentionally introduced as commodities, e.g. by the pet trade, the live food trade, or as stock for the trade in fur pelts [9,31-33]. Although some of these pathways have been modified and restricted to reduce the risk of invasion, many remain very active. For example, the pet trade remains a dominant pathway for the introduction of new invasive species to Europe [31,32].

Many other terrestrial animal species, especially invertebrates, have been introduced across Europe unintentionally, mostly as stowaways or contaminants on traded products, on vehicles (e.g. ships), or as diseases/parasites of plants, animals, and humans [9,31-33]. In general, much less is known about introductions of species that were introduced unintentionally because they are usually not recorded until they become established.

\section{Terrestrial plants}

Almost two thirds $(62.8 \%)$ of the established plant species in Europe were introduced intentionally for ornamental, horticultural, or agricultural purposes. The remaining species were introduced unintentionally, mostly associated with transport vectors, or as contaminants of seeds and other commodities [34]. Of the terrestrial plant species that have escaped from human cultivation, some were intentionally released (i.e. planted in the wild to 'improve' the landscape), some were contaminants or stowaways, and only a few arrived unaided [9]. Consistent with increases in international trade, there has been a steady increase in the number of established non-native terrestrial plant species discovered in Europe, especially since 1800 . Currently, an average of 6.2 species not native to any part of Europe is newly 
Table 1 Some important pathways of introduction for non-native terrestrial animals, terrestrial plants, and aquatic organisms

\begin{tabular}{|c|c|c|c|}
\hline Group & Sub-group & Dominant pathways & References \\
\hline \multirow[t]{3}{*}{$\begin{array}{l}\text { Terrestrial } \\
\text { vertebrates }\end{array}$} & Mammals & $\begin{array}{l}\text { Intentional introduction as commodity (for hunting, 'fauna improvement', fur farming, as pets, } \\
\text { or for zoos), then either intentional release or accidental escape }\end{array}$ & {$[9,31]$} \\
\hline & Birds & $\begin{array}{l}\text { Intentional introduction as commodity (for hunting, 'fauna improvement', as pets, or for zoos } \\
\text { or bird parks), then either intentional release or accidental escape }\end{array}$ & {$[9,32]$} \\
\hline & Reptiles/amphibians & $\begin{array}{l}\text { Intentional introduction as commodity (for 'fauna improvement', as pets, food source, or } \\
\text { biological control agents), then either intentional release or accidental escape }\end{array}$ & {$[9,32]$} \\
\hline \multirow[t]{2}{*}{$\begin{array}{l}\text { Terrestrial } \\
\text { invertebrates }\end{array}$} & Insects & $\begin{array}{l}\text { Unintentional introduction as contaminants or stowaways, sometimes deliberate release as } \\
\text { biological control agents }\end{array}$ & {$[9,33]$} \\
\hline & Other & Unintentional introduction as contaminants or stowaways & [33] \\
\hline $\begin{array}{l}\text { Terrestrial } \\
\text { plants }\end{array}$ & $\begin{array}{l}\text { Vascular plants, } \\
\text { mosses, and lichens }\end{array}$ & $\begin{array}{l}\text { Intentional introduction as commodity for garden trade (ornamentals), horticulture, } \\
\text { unintentional introduction as contaminant of plants introduced for agriculture and } \\
\text { ornamental trade (e.g., soil contaminants in plant pots) }\end{array}$ & {$[9,10,34,126]$} \\
\hline \multirow[t]{4}{*}{$\begin{array}{l}\text { Aquatic } \\
\text { organisms }\end{array}$} & Fishes & $\begin{array}{l}\text { Intentional introduction for aquaculture, stocking to improve recreational and commercial } \\
\text { fisheries (including illegal stocking), as well as for weed and mosquito control, unintentional } \\
\text { introductions with ship ballast water, ornamental species, fishing bait releases }\end{array}$ & {$[75,127]$} \\
\hline & Crustaceans & $\begin{array}{l}\text { Intentional introduction for aquaculture, ornamental reasons (Decapoda), unintentional } \\
\text { introductions with ship ballast water, canals }\end{array}$ & {$[38,128-130]$} \\
\hline & Mollusks & $\begin{array}{l}\text { Unintentional introductions with shipping, waterways, accidental (e.g. during fish stocking), } \\
\text { but also from garden pond and aquarium trade }\end{array}$ & {$[131,132]$} \\
\hline & Plants & $\begin{array}{l}\text { Intentional introduction for ornamental (aquarium and watergarden) trade, often further } \\
\text { spread by boats and waterbirds }\end{array}$ & {$[133,134]$} \\
\hline
\end{tabular}

Pathways of introduction for organisms established in Europe. Pathway lists given are not comprehensive and were chosen to give an indication of the total range of vectors, not necessarily those that are most important for each group.

recorded as established each year. An average of 5.3 European species are found in parts of the continent outside their native range each year [10].

Much less is known about the introduction and spread of non-native lower plants and fungi, and about changes in the number of non-native species in Europe over time. It is known that these taxa can have enormous impacts, with perhaps the most damaging examples being diseases of crops and livestock. The potato famines that occurred across Western Europe during the nineteenth century, for example, were caused by the invasive potato blight (Phytophthora infestans) [35], introduced from North America.

\section{Aquatic organisms}

The pathways of introduction for aquatic organisms are generally known with less precision than those for terrestrial organisms. This arises partly because many aquatic species are introduced unintentionally with few (if any) records kept. Additionally, the difficulty of sampling in marine and freshwater environments means that a species may be well established, and may have spread from its initial site of introduction, before it is recorded.

Shipping has been by far the dominant pathway for the introduction of non-native marine species to the European Atlantic coast (47\% of established non-native species) and to the Baltic Sea (45\%, [36]). This pathway has also been a significant factor in freshwater animal introductions to Europe (25\% of established non-native species, [37]). The shipping network creates connections among aquatic ecosystems across the globe, and organisms are frequently transported in the ballast water of ships, or attached to hulls as fouling organisms [28]. Ballast water is taken on to increase a vessel's weight when it is not fully laden with cargo. As this water is taken on, any organisms in the water are also sucked in. Vessels then travel to subsequent ports, and surviving organisms can be discharged with ballast water if the vessel takes on more cargo.

The opening of canals that link previously isolated water bodies has created many opportunities for the introduction and spread of non-native species. In the Mediterranean Sea, 54\% of established non-native species arrived by dispersing through the Suez Canal [36]. Canals have also had a profound impact on the establishment and spread of non-native freshwater species in Europe, and this impact is tightly linked to shipping. There are now river and canal connections running from the Black Sea across Europe to the mouth of the Rhine River, and north to the Baltic Sea [38]. These connections have served as invasion corridors for many species native to the Ponto-Caspian into Western and Northern Europe. It is estimated that $8 \%$ of non-native freshwater animal species in Europe arrived by using natural dispersal mechanisms to move through canals [37]. In addition, many of the species that arrived through shipping (see previous paragraph) could only do so because of the existence of canals. 
Despite the influence of shipping and canals, the most important pathways for the introduction of non-native freshwater animal species to Europe have been stocking (30\% of species) and aquaculture (27\%) [37]. Stocking has been largely of fish to create new wild populations, while aquaculture introductions have arisen from the unintended escape of farmed species and their associated organisms (e.g. parasites). Aquaculture has also been important for introductions of marine species to the Atlantic coast, Baltic Sea, and Mediterranean, accounting for $24 \%, 18 \%$, and $11 \%$ of established species, respectively [36].

The final pathways mentioned here are the trades in ornamental (predominantly aquarium and watergarden) and aquaculture species. Ornamental introductions have been especially important in freshwater ecosystems, accounting for $8 \%$ of established non-native animal species. Ornamental introductions also appear to be by far the dominant pathway for introduction of aquatic plants. For example, in Great Britain 22 of 31 established non-native freshwater plant species were introduced for the ornamental trade [8]. The aquaculture trade has unintentionally introduced a large number of non-native aquatic species as contaminants of intentionally introduced species such as fish or shellfish. This is true for both marine and freshwater habitats. For example, the unintentional introduction and spread of the brown algae Sargassum muticum, the Japanease kelp Undaria pinnatifida, and the snail Ocinebrellus inornatus, as well as the oyster parasites Mytilicola orientalis and Myicola ostreae, all occurred because these species inadvertently arrived associated with marine shellfish imported from Asia to Europe for aquaculture [36].

\section{Characteristics of highly invaded regions}

The number of invasive species found in a region depends on the number of species that have been introduced, the proportion of introduced species that have become established, and the proportion of established species that have gone on to cause impacts. When investigating differences among regions, invasion biologists have generally left aside the pathways and process of introduction and focused instead on the proportions of introduced species that become established, and of established species that become invasive [39]. Ecosystems where these proportions are high have been assumed to be highly invasible, while others have been deemed relatively resistant.

Different theories have been proposed to explain why some regions appear more invasible than others. Perhaps the most influential has been the biotic resistance hypothesis, an early champion of which was Charles Elton, often referred to as the scientist who founded the field of invasion biology (e.g. [19]; although we note that Charles
Darwin [40] and other biologists had already written about the spread and impacts of non-native species, $[11,41])$. This hypothesis holds that regions with high biodiversity and a relatively low level of disturbance, especially disturbance from humans, are more resistant to establishment by non-native species [42]. The rationale is that less diverse and/or more disturbed ecosystems are likely to have more vacant niches that introduced species can inhabit. Although this is an intuitively appealing argument, there has been little empirical evidence generated to support it. In fact, especially at larger spatial scales, there is increasing evidence that highly diverse habitats are actually more prone to non-native species establishment (e.g. [43-45]. Several authors have attempted to reconcile the contrasting theory and evidence, but no consensus has yet been reached (e.g. $[46,47])$. A large obstacle to finding this consensus comes from the difficulty of quantitatively assessing levels of disturbance and the presence of vacant niches.

As well as trying to reconcile theory and observed patterns in species establishment, ecologists are now paying more attention to the introduction process. Recent results show that the number of species introduced to a region may be at least as important as the invasibility of the region in determining how many species become established [48-52]. This is discussed further in the following sections.

\section{Terrestrial animals}

There is a particular lack of support for the biotic resistance hypothesis when terrestrial animals are considered (see [52] and references therein). It has become clear in recent years that the key difference among regions with different numbers of established terrestrial animals is the number of species that have been introduced. But which regions are the ones that receive more introductions than others? The answer is that regions with high human impact typically receive more species introductions than other regions, and that this leads to them containing more established species. For example, 12 non-native mammal species have established in France, nine in Germany, but just two in Portugal. Contrary to what would be predicted from the biotic resistance hypothesis, it is not easier for introduced mammals to establish in countries with high human impact, but these countries host more non-native mammals than other countries because they have received more species introductions [52]. Differences among the number of established birds in European countries can also be best explained by differences in number of introduced species [51].

\section{Plants}

Patterns of plant invasion in Europe offer little support for the biotic resistance hypothesis (e.g. $[44,53,54]$ ). 
Instead, apart from broad habitat type, the number of species introduced and their propagule pressure appear to be the most important determinants of the number of established non-native species in any given region (e. g. $[55,56])$. The most invaded habitats in Europe are in heavily transformed landscapes such as agricultural land, coniferous forests, urban areas, and dump or construction sites [57]. In contrast, natural and semi-natural environments such as broad leaved and mixed forests, pastures, natural grasslands, moors, heathlands and peatbogs have remained relatively uninvaded [57]. This pattern is consistent with that observed for terrestrial animals - that sites experiencing high levels of human disturbance and high propagule pressure tend to be the most invaded. Disturbance increases plant invasions because it leads to loss of native species that could compete with introduced non-native species, and because it increases availability of resources [58]. High propagule pressure occurs in the same regions because human activities lead to many plant introductions [59].

The highest proportions of established terrestrial plant species in Europe occur in agricultural landscapes, especially in eastern Britain, northern France, Central and Eastern Europe, and the Po floodplain in Italy. In contrast to a global pattern of Mediterranean-type ecosystems being highly invaded, the European Mediterranean biogeographic region is relatively uninvaded, probably due to a long history of human presence and prehistoric introductions in the Mediterranean Basin, which may make its ecosystems relatively resistant against recently introduced species [57]. Additionally, the Mediterranean Basin acted as more of a donor than recipient region for species introductions during the colonization of the New World [60].

It has been argued that harsh environments (e.g. alpine habitats) might not be suitable for non-native species. However, these are also often the habitats that experience low propagule pressure [61]. Hence, it is clear that the intensity of human activities that increase or facilitate propagule pressure, pathways of introduction, intensity of disturbance, and eutrophication, are important determinants of non-native plant invasions. For many taxa in Europe, it is even more important than climate or other features of the physical environment [62].

\section{Aquatic organisms}

European aquatic ecosystems containing the highest numbers of non-native species tend to be those with high connectivity to other ecosystems, high frequency of human access (e.g. for transportation or recreation), and high disturbance. These include boat harbours, recreational areas at lakes (jetties etc.), and the many canals that now cross Europe. More remote water bodies, including mountain lakes and headwater streams, tend to be least and last invaded. Thus, propagule pressure can largely explain the intensity and diversity of established non-native species in aquatic environments $[3,20]$. In marine ecosystems, the number and frequency of pathways, tidal movements, availability of empty niches, and availability of different substrate types for settlement are the main factors that determine susceptibility to invasion, with highest rates of non-native species establishment typically found in shallow coastal zones [36]. Consequently, marine ecosystems with high numbers of established species in Europe include the eastern Mediterranean with hundreds of introductions through the Suez Canal [63], as well as the Gulf of Finland, the Gulf of Riga, the coastal lagoons [64-66], and the Oosterschelde estuary [67]. Of the 737 non-native multicellular animal species recorded from European seas, 569 have been found in the Mediterranean, 200 along the Atlantic coast (Norway to the Azores, including the UK and Ireland), and 62 in the Baltic Sea [36]. Numbers in the Mediterranean are highest because of the Suez Canal, the role of the Mediterranean as a long-time hub of international shipping, and a surge in development of mariculture [36].

\section{Characteristics of invasive species}

An alternative perspective comes from asking whether there are traits of non-native species that are associated with successful passage through the invasion process. Ecologists have been asking this question for several decades (e.g. [68]), often concentrating on intuitive lifehistory traits such as early reproduction, high reproductive output, or a non-specialized diet (reviewed by $[69,70])$. This work has recently become more important because many nations, including several in Europe and the European Union, have begun to develop risk assessment programs for non-native species [71-75]. The development of risk assessment tools begins with the search for patterns in species traits that are associated with successful passage through the invasion process. If robust patterns are identified, they can be applied to non-native species to determine the likelihood that they will become established, spread, and/or become invasive (see $[2,76,77]$ for reviews). In this way, knowledge of non-native species traits can support pro-active efforts to prevent new invasions.

Although the search for traits of invasive species has been fruitful, recent results have shown that propagule pressure can be confounded with invasiveness [39]. As for the discussion above that focused on differences in invasibility among regions, invasion biologists have traditionally left aside introduction and focused on establishment and spread when looking for differences between the traits of invasive and non-invasive species. 
Recent studies have challenged this by showing that those species most likely to establish are often those introduced in the highest numbers and most frequently. This does not mean that the search for traits of invasive species is not worthwhile, but does indicate that additional factors are important.

\section{Terrestrial animals}

Recent studies of the characteristics of invasive terrestrial animal species have shown that invasive species tend to have been introduced in higher numbers and more frequently than non-invasive species $[69,78]$. Mammals and birds that are hunted by humans are more frequently invasive than other species of mammals and birds because they have been more frequently introduced than other species, even though their establishment success is not higher than that of other species [69]. The same is true for mammals and birds with large native ranges which also become invasive more frequently than species with smaller native ranges. Their establishment success has not been shown to be higher than that of non-native species with smaller native ranges, meaning that this pattern is best explained by their increased frequency of introduction [69,79].

Terrestrial animals living in association with humans tend to become invasive more often than other species [69]. Good examples are the Norway rat (Rattus norvegicus) which reaches extremely high population densities in cities; the rose-ringed parakeet (Psittacula krameri), native to Africa and Asia and also often very abundant in human settlements; and the harlequin ladybird (Harmonia axyridis), native to Asia and infamous for its large aggregations in buildings during winter [6]. Thus, a clear understanding of human activities, both in terms of propagule pressure and the location of human settlements, is very important for understanding patterns of establishment, spread, and harm for non-native terrestrial animals.

There are also species-level biological traits linked to terrestrial animal invasiveness. For example, behavioural flexibility as expressed by brain size was among the best predictors of invasiveness in a study of non-native birds [80]. Mammals and birds with high ecological flexibility (indicated by the number of different types of food they consume or the number of different types of habitat they use) also tend to be more invasive than other species $[69,81,82]$. Thus, species that are relatively more behaviourally and ecologically flexible tend to become invasive more often than other species.

\section{Terrestrial plants}

Several factors are related to the invasion success of individual plant species. First, non-native plants that have been introduced and/or planted more frequently (i.e. higher propagule pressure) are more likely to become established and to have a larger range (e.g. [83]). Second, residence time (i.e. time since introduction) in the nonnative range is important, with those species that have been present for longer tending to have larger ranges [84]. This is an effect of having the opportunity to fulfil more life cycles and also simply having the time to spread further. The importance of residence time is also associated with propagule pressure, as species that were introduced a long time ago are likely to have been introduced many times since the first introduction. Third, species with larger native ranges are more likely to successfully establish beyond their native range. Similar to terrestrial animals, this is presumably associated with a higher probability that the species will be accidentally transported [85]. Additionally, species with a large native range are more likely to have a strong climate match to at least part of Europe, making them pre-adapted to survive there. Fourth, once terrestrial plant species have been introduced to the new range, traits of the species are important for determining whether they will successfully establish, spread, and cause harm. Traits known to promote passage through the invasion sequence include long flowering season, being an annual, vegetative spread, having multiple dispersal vectors [85], high maximum relative growth rate, and high resource allocation to shoots and leaves $[86,87]$.

Many studies that have attempted to relate biological traits to invasiveness have explained little of the variation and have neglected trait interactions. Including interactions among traits (i.e. explicitly considering that one trait value might have a different influence on invasion success in the presence of other traits) can result in much better explanatory models. Küster et al. [88] found that trait interactions accounted for $>40 \%$ of the variation that could explain invasion success of non-native terrestrial plants in Germany. Interestingly, long flowering season was beneficial for self-pollinated species, but was disadvantageous for wind pollinated species, and had no effect on insect-pollinated species. Furthermore, the effect of timing of the end of the flowering season on invasion success differed among plant species with different vegetative reproduction strategies or different levels of ploidy (number of chromosome sets in the cell). Thompson and Davis [89], however, argue that such analyses tell us very little because successful invaders do not differ in their traits from those of widespread native plant species. Despite this critique, incorporating statistical interactions among traits should increase our knowledge of characteristics that make a species likely to expand or contract its range, whether non-native or native.

\section{Aquatic organisms}

As for terrestrial animals and plants, there are some general rules that separate non-native aquatic species 
that successfully pass through the invasion sequence from those that do not. Some of the characteristics that influence invasion success are associated with biological traits whereas others are closely linked to interaction with humans. For example, species introduced intentionally (and hitchhiking species associated with them) because they have desirable attributes tend to be more successful than undesired species. Prominent examples in marine environments include the introductions of alien shellfish species (e.g. Crassostrea gigas introduced to France from Japan) for mariculture, which have arrived with several associated parasites and algae. Additionally, many of the most widespread non-native aquatic species in Europe are generalists that can tolerate a wide range of environmental conditions such as water temperature and salinity. European brackish water systems hold a great diversity of invaders which may be due to their poor native species richness [90] and the great ecological plasticity of the non-native species that have established. In addition to the breadth of ecological niches, similarity of environmental conditions in the donor and the receiving region can also be crucial [28]. For example, most of the 569 non-native species in the Mediterranean are thermophilic and originated from tropical waters in the Indo-Pacific, the Indian Ocean, the Red Sea, and pan-tropical regions [36].

Differences in life history and reproduction can differentiate between invaders and rare species. This is evident in freshwater unionid mussels, which are among the most critically imperiled freshwater taxa both in North America and Europe [91,92]. These species produce glochidia larvae that need to attach to a suitable fish host to survive. The high degree of specialization and the complex life cycle of unionids probably contribute to the decline in this group. In contrast, invasive mussels of the genus Dreissena are less specialized and produce free veliger larvae, allowing for a higher rate of dispersal through passive transport (e.g. in the ballast water of ships). Non-native marine species, which have been predominantly introduced to Europe through shipping, are also more likely to have larval stages that are tolerant of conditions in ships.

Reproduction rates tend to be higher in invasive aquatic species compared to those in most non-invasive species (e. g. [93]). High reproduction can facilitate rapid spread and secondary introductions into other areas. Mode of feeding can also be important, with filter-feeding freshwater macroinvertebrates in Europe and North America known to be more successful at invading than predator macroinvertebrates [94]. This has the impact of enhancing energy flow between benthic (i.e. bottom) and pelagic (i.e. open water) regions because algae that are produced mostly in the pelagic zone are consumed by the benthic filter feeders. For intentional introductions of fishes, where large predator species tend to be most popular, competition and top-down regulation may be more important. Overall, effects of non-native species tend to be greater when they establish in high abundance and have strong functional distinctiveness from native species [95].

\section{Number of established non-native species in Europe}

At least several thousand non-native species are now established in Europe [6]. These include species not native to any part of Europe, as well as species native to one part but now established in another. The following sections give estimates of the number of species in different habitat categories that are established in Europe and not native to any part (unless stated otherwise). These figures should be seen as low estimates of the true numbers of established species because only recorded species are included; it is likely that many additional species are established but not yet recorded.

\section{Terrestrial animals}

According to the DAISIE database, there are 33 nonnative established mammal species [31] and 77 established bird species in Europe [32]. These figures are probably quite accurate because these taxa are relatively large and easy to distinguish from native species. For the same reason, the estimate of 55 established reptiles and amphibians in Europe [32] is also probably quite accurate. In contrast, estimates for invertebrates are likely to be more severe underestimates because these species are more difficult to collect and identify. Within terrestrial invertebrates, data for insects tend to be more accurate than those for other invertebrates [33]. Insects are also the dominant group among non-native terrestrial invertebrates in Europe: of 1,522 established species, 1,306 (86\%) are insects [33]. This high proportion is not unexpected, however, as $85 \%$ of the world's known invertebrates are insects [96].

\section{Terrestrial plants}

Terrestrial plants are generally well sampled, but it can be difficult to assess total numbers of established nonnative species because the same species is often given different scientific names in different parts of Europe. According to the DAISIE database [10], 5,789 plant species have been recorded from the wild (not necessarily established) in at least one European country to which they are not native. These species come from 213 families and 1,567 genera, and include 2,843 species not native to any European country. A total of 3,749 plant species are known to be established in at least one European country to which they are not native, and 1,780 of these species are entirely non-native to Europe. We note that the numbers just given include all species 
recognized as non-native, irrespective of their date of introduction [97]. Traditionally, in those countries where records are available, botanists distinguish between species introduced before the European discovery of the Americas (1492) and those introduced later.

\section{Aquatic organisms}

It is estimated that 737 non-native multicellular animal species from marine environments and 262 non-native freshwater animal species are now established in Europe $[36,37]$. These comprise a wide range of taxa, including fishes, arthropods, mollusks, platyhelminthes, and annelids. For aquatic plants, it is estimated that at least 260 species not native to any part of Europe are established in inland waterways [34].

The number and diversity of non-native species is variable across different regions of Europe. For example, in Great Britain the 134 established non-native species in freshwater ecosystems are dominated by plants (31), fishes (18), non-decapod crustaceans (17), platyhelminths (15), and amphibians (11; full list in [8]). In Italy, the patterns are somewhat different, with the 112 nonnative species from inland aquatic systems being dominated by fishes (38), non-decapod crustaceans (28), and gastropods (7; full list in [98]). In each case, it is reasonable to expect that non-native species from groups such as fishes and crayfishes are better represented in the data than records of species that are smaller and less often sampled (e.g. annelids).

Just seven non-native vascular plants have been identified in European marine ecosystems [34]. In contrast, numbers of non-native marine species (i.e. including animals and other multicellular organisms) are much larger. The three main marine biogeographic regions of Europe are the Mediterranean, the Atlantic coast, and the Baltic Sea; these contain 569, 200, and 62 established nonnative species, respectively [36]. These species cover a large taxonomic range, from fishes to barnacles to plants.

\section{Impacts of non-native species in Europe}

Invasive species have a large and diverse range of impacts in Europe. This diversity of impacts is mainly driven by the diversity of species, and makes generalized statements about types of impact difficult. However, it is clear that invasive species have significant negative impacts on many native species and almost all ecosystems, on the European economy, and on human health (recently reviewed by [7]). Economic impacts alone are estimated to be at least 12.5 billion EUR per year, and are probably over 20 billion EUR [99].

\section{Terrestrial animals}

Ecological impacts of invasive terrestrial animal species include predation/herbivory, competition, transmission of diseases, and hybridization with native species. Economic effects include impacts on human infrastructure, human health, human social life, livestock, plant production, and forestry $[7,100,101]$. For example, Norway rats (Rattus norvegicus) predate many native species and have caused declines in native bird species and small mammal species. They are also a reservoir and vector of many diseases, including hepatitis E, leptospirosis, hantavirus, and Q fever. The invasive American mink (Neovison vison) is a competitor of the European mink (Mustela lutreola) which is now listed as endangered on the IUCN Red List of Threatened Species. Another example of an invasive competitor of a native species is the North American grey squirrel (Sciurus carolinensis, Figure 1A) that threatens the native red squirrel (Sciurus vulgaris), especially in the U.K. and Italy. The Canada goose (Branta canadensis, Figure 1B) is also an abundant invader. It hybridizes and competes with native geese, and its droppings can cause human health hazards and algal blooms. The Asian tiger mosquito (Aedes albopictus) competes with native mosquito species; its bites are a nuisance to humans, and it is a vector for diseases such as West Nile virus. Another invasive terrestrial invertebrate with severe impacts is the harlequin ladybird (Harmonia axyridis). Its tendency to overwinter in large aggregations inside buildings is a nuisance to many people, and the unpleasant odour of its body fluids can destroy the taste of wine. It also threatens native ladybirds and other European insect species [6]. Overall, invasive terrestrial invertebrate species cause costs of at least 1.5 billion EUR per year in Europe, and invasive terrestrial vertebrates cause costs of at least 4.8 billion EUR per year [99].

\section{Terrestrial plants}

Many invasive plant species in Europe are primarily recognized as agricultural or forestry weeds. Additionally, 17 out of the 18 plant species recorded among the most damaging invasive species in Europe [6] are known to reduce the habitat of native species [34]. Eight of them are reported to disrupt community assemblages, for example by impacting plant pollinator networks [34]. Non-native plant species can also hybridize with closely related native species so that distinctive genotypes of native plants are lost [102]. Species such as Japanese knotweed (Fallopia japonica) and Himalayan balsam (Impatiens glandulifera) grow and are nuisance species along railway lines (the former) and waterways (both). Other plant species can cause severe health problems. For example, giant hogweed (Herracleum mantegazzianum, Figure 1C) produces sap that causes skin lesions to humans upon contact [103]. The pollen of invasive ragweed (Ambrosia artemisiifolia, Figure 1E) is highly allergenic to humans, and estimates of associated 

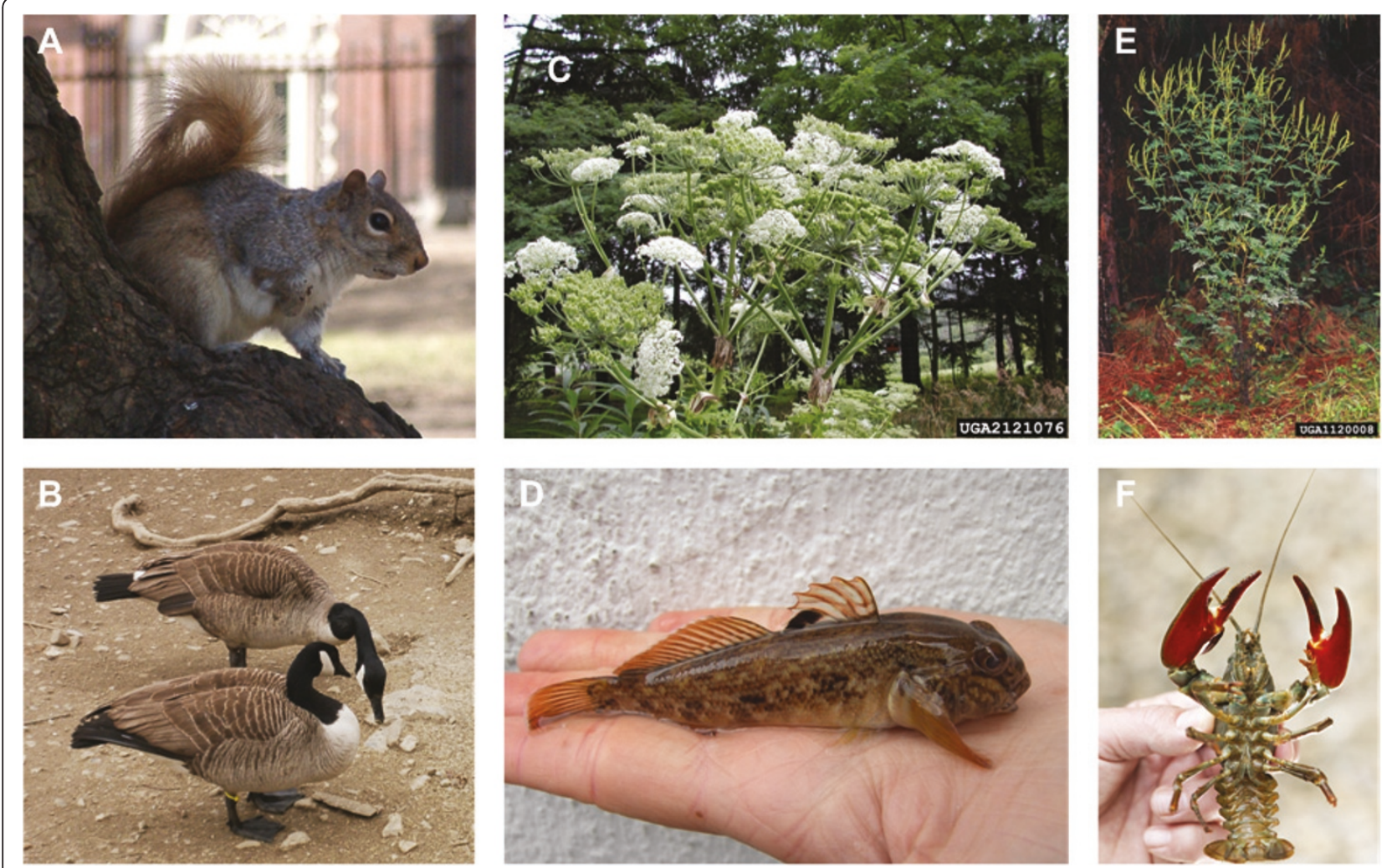

Figure 1 Examples of high-impact invasive species in Europe. (A) grey squirrel (Sciurus carolinensis), native to North America, ${ }^{\circ}$ Jeschke; (B) Canada goose (Branta canadensis), also native to North America, ${ }^{\circ}$ Jeschke; (C) giant hogweed (Heracleum mantegazzianum), native to the Caucasus region, ${ }^{\circ}$ Denholm, NJ Dept of Agriculture, Bugwood.org; (D) round goby (Neogobius melanostomus), native to the Caspian, Black, and Azov Seas, ${ }^{\circledR}$ Aquatic Systems Biology Unit, TUM; (E) common ragweed (Ambrosia artemisiifolia), native to North America, ${ }^{\circledR}$ Bodner, Southern Weed Science Society, Bugwood.org; (F) signal crayfish (Pacifastacus leniusculus), native to North America, ${ }^{\circledR}$ Aquatic Systems Biology Unit, TUM.

medical costs in Germany range between 17 and 47 million EUR annually [104]. According to Vilà et al. [7], the most costly plant invaders affecting nature conservation, agriculture, forestry, and fisheries in Europe are pigface species (Carpobrotus spp.). These produce annual costs for control and eradication in Spain of approximately 0.58 million EUR [105]. Overall, invasive terrestrial plants cause costs of at least 3.7 billion EUR per year in Europe [99].

\section{Aquatic organisms}

Invasive species are considered one of five major threats to aquatic biodiversity worldwide [4], with particularly large impacts on freshwater habitats $[106,107]$. The isolated nature of most freshwater habitats means that natural spread of aquatic organisms into new habitats occurs at low frequencies. In turn, this means that aquatic communities tend to be more different to each other, and thus that the increased rates of species movement caused by human pathways have large potential for impacts on biodiversity.
Traditionally, the study of invasions in aquatic ecosystems has had a strong focus on economically important and visible species, whereas invasive populations of small taxa (e.g. plankton) or groups that are difficult to identify at the species level (e.g. chironomids) have rarely been considered. As a larger and more visible species, North American signal crayfish (Pacifastacus leniusculus, Figure 1F) have been relatively well monitored and recorded. They were introduced to Europe primarily for aquaculture, have spread rapidly, and are now considered one of the major threats to the indigenous crayfish fauna [108]. In addition to their competitive behaviour [109], North American crayfish are hosts of the crayfish plague (Aphanomyces astaci), an oomycete fungus that causes a lethal disease to European crayfish [110]. Also, the introduction of non-native salmonids and gobiids (e.g. Neogobius melanostomus, Figure 1D) has resulted in the decline and even extinction of indigenous species, and caused ecosystem shifts in lakes and streams [6,111]. In economic terms, the zebra mussel Dreissena polymorpha, which can completely block 
cooling systems in hydropower plants, probably has the greatest impact of all freshwater invaders.

In marine habitats, negative effects of non-native species include declines in native species richness and abundance. These impacts have been associated with the invasion of Caulerpa taxifolia into the Mediterranean [112], and with the high mortality rates of European oysters (Ostrea edulis) due to competition with introduced Pacific oysters (Crassostrea gigas) and damage from introduced parasites. Despite these examples, there is little comprehensive evidence for most impacts of invasive marine species, and there are some examples of economic benefits. For example, the release of the red king crab (Paralithodes camtschaticus) into the Barents Sea and its southward spread along the Norwegian coast has provided an additional fishery and income for fishermen in the order of 9 million EUR per year [36]. Nonetheless, negative impacts of invasive aquatic species in Europe are high and have been estimated to cost at least 2.2 billion EUR per year [99].

\section{Management and policy for invasive species Policy challenges}

Compared to other environmental problems, invasive species present at least six particular challenges. First, their impacts tend to increase over time as populations become larger and spread [113]. In contrast, other environmentally damaging activities, such as the release of chemical pollutants, generally decrease in severity over time after the activity is ended. This means that populations of invasive species can best be managed through rapid eradication of new populations [114]. This is most feasible soon after a species becomes established, but the type of biological information needed to support eradication and the resources and political will to eradicate a harmful invader are generally not available until the species has spread and become invasive. By this point there are fewer options to control the population, and the level of resources required, and the possibility for undesirable side effects on other ecosystem components, are usually prohibitive.

Second, many other issues for environmental policy, such as forestry and mineral exploration, can be effectively managed with little concern for the policies followed by one's neighbours. In contrast, invasive species readily cross borders as long as there is suitable habitat on the other side [1]. This means that efforts to prevent invasions need to be mindful of the efforts being made in neighbouring jurisdictions [1]. As European economies become more integrated there are fewer barriers, such as border checks, to the spread of invasive species.

Third, invasive species often travel as contaminants of valuable trade. For example, most large ships carry ballast water to increase their weight when they are not fully loaded with cargo. This ballast is taken on at one port, along with any organisms in the water, and discharged at subsequent ports as cargo is loaded. Unintentional transfer of organisms in ballast tanks is now the largest single cause of marine invasions [115], and a strong factor in freshwater invasions [28,116]. Reducing the spread of invasive species via this pathway would either require constraints on where ships travel, or the installation onto all ships of expensive ballast treatment technology. Either of these options would increase the cost of shipped goods. Thus, control of invasive species often involves trade-offs with other activities, complicating decisions about how impacts can best be managed [114].

Fourth, it is usually impossible to determine the exact conditions that will lead to an invasion. Risky activities, such as collecting ballast water in one port and dumping it in another, may occur many times before an invader becomes established. The invasion of the Laurentian Great Lakes by zebra mussels (Dreissena polymorpha) in the late 1980s, for example, had been predicted for over a century before it actually occurred [117]. These predictions were based on shipping connections between the Great Lakes and regions where zebra mussel was established, and on the fact that the species is well suited to Great Lakes conditions. Why it took so long for the invasion to occur and why it occurred when it did remains unknown. This general uncertainty about invasions complicates management because economic activities with definite and well-quantified immediate benefits must be balanced against risks from the stochastic invasion process [118].

Fifth, controlling the spread of invasive species requires international cooperation, and this is often difficult to achieve [1]. For example, in response to the risk from ballast water invasions, the International Maritime Organization (IMO) produced the International Convention for the Control and Management of Ships Ballast Water and Sediments in February 2004. This convention requires the establishment of ballast water management systems on ships, with the goal of preventing the movement of live organisms. The dates at which each ship would be required to have ballast water treatment facilities differ based on ship size and age, but fall between 2009 and 2016. Despite this convention being finalized for several years and despite a widespread consensus that its implementation could reduce rates of invasion, it has not yet come into effect because too few countries have ratified it. Many other pathways of species invasion could be best managed at an international level, but policies have rarely been negotiated and implemented at this level [1].

Finally, there is often a considerable time lag, occasionally as much as several centuries, between the 
introduction of non-native species and their spread. These time lags appear to be especially long for terrestrial plants [12]. In a recent paper, Essl et al. [13] have shown that this may lead to an 'invasion debt' in which human activities many decades ago may have already set in process invasions that have not yet been recorded. In their paper, Essl et al. [13] showed that for several groups of plants and animals the socio-economic conditions in Europe during 1900 were more closely related to current levels of invasions than conditions in the year 2000 , even though many species were introduced in the second half of the twentieth century. This means that current activities in Europe may be setting in motion many future invasions.

\section{Bioeconomic approaches to policy and management}

Ecological studies of species invasions have increased in number and sophistication over the last several decades [19]. This has created a much clearer picture of the number of species that are established beyond their native range, and the types and severity of impacts that they cause. Recognition of these impacts has led to increased calls for management and policy (e.g. [119]). Although many nations now have policies to reduce the impacts of invasive species, invaders continue to arrive at an increasing rate, indicating that the results from ecological studies have not prompted sufficient changes in policy and management.

Concurrent with advances by ecologists, economists have taken an interest in the problems of invasive species. Much of their interest centres on the trade-offs that must be made to manage invasive species [114]. For example, economists might make the link between a beneficial trade route and the risks from invasions that it causes. They can then ask if and how the trade route can be restricted or modified to reduce risks from invasive species while maximizing overall societal welfare (e. g. [120]).

Although ecologists and economists have often addressed similar concerns (i.e. how to reduce the impacts of invasive species), they have rarely worked together. This stems in part from a lack of understanding between the disciplines. In particular, ecologists may be unwilling to consider ecosystem components/qualities (e.g. biodiversity) in monetary terms. On the economist side, there is often a lack of willingness to work with ecological systems because they are so complex, in many cases are poorly understood even by ecologists, and because the relationships among ecosystem components may not fit into traditional economic models.

As described above, the introduction of non-native species is a consequence of the globalization of trade and travel. The benefits to society from globalization are large, as are the benefits from non-native species used in agriculture, horticulture, forestry, fisheries, landscaping, and the pet trade, etc. Thus, the benefits from policy that prevents and manages invasions must be balanced against the costs of the policy, including the costs of restricting trade. In practical terms, this requires a good understanding of both the ecological and economic dimensions of invasions, and requires that economists and ecologists work together to design appropriate policies.

\section{General principles for policy and management}

It is generally accepted, and has often been shown, that the best way to reduce total impacts from invasive species is to prevent their introduction $[113,119,121]$. For example, studies have shown that preventing the spread of an invader among lakes [122,123], and the spread of species among countries through trade [120], is economically preferable to managing species after they arrive. If prevention of all introductions is not feasible, efforts to reduce propagule pressure should be the goal as this may effectively prevent a proportion of invasions. Prevention is considered more effective than managing established invaders for at least three reasons. First, it is the only sure way to avoid impacts of invasive species, which as noted above are rarely eradicated. Second, there are more management options available prior to invasion. These include a variety of laws and regulations, quarantine efforts, and the threat of punitive action against individuals or companies that do not comply. Finally, prevention efforts give the opportunity to shift the costs of reducing impacts to the trades that derive greatest benefits from the movement of species [1]. For example, although the pet trade has introduced many harmful invaders around the world, the exporters, importers, and retailers who derive greatest benefits from the trade have not been required to pay the costs. Instead, those costs are generally borne by society as government agencies work to control invaders. Prior to invasion, however, it is possible to impose regulations that require the trades to ensure that they are not transporting potential invaders. Thus, the externality of trade can be internalized.

Post-establishment, the broad range of invasive species and the ecosystems they become established in, and the heterogeneous ways that humans value those ecosystems, means that few generalizations can be given for management and policy. That is, appropriate management and policy for harmful invasive species is highly context dependent. Options include poisoning (e.g. herbicides, pesticides, piscicides), manual removal (e.g. pulling plants), capturing and killing (e.g. trapping, shooting), and release of additional species that may provide biological control of the invader. As the applications of these methods are context dependent, and 
because different countries within Europe have different standards for the application of these methods, they are not explored further here. The general principle of prevention still applies, however, and efforts to slow or eliminate population spread will often be the most costeffective ways to reduce total impacts.

\section{Invasive species policy in Europe}

There is a large diversity of national approaches to invasive species within the EU (see review in [124]). These range from relatively advanced policies and procedures, such as in the Netherlands where there is a national policy framework for addressing invasive species, to nations that do relatively little to prevent the arrival and spread of invaders. Open internal borders, however, create a weak-link problem in the $\mathrm{EU}$ where even nations with the most stringent policies remain at risk because some of their neighbors and trading partners are doing relatively little [1].

At the international level there are several instruments that address the threats from invasive species. These include the Convention on Biological Diversity (CBD, implemented into European legislation by Council Decision 93/626/EEC), which requires ratifying nations to work to prevent the introduction, spread, and export of all types of invasive species (http://www.cbd.int/). There is no history, however, of nations being sanctioned for not following the invasive species guidelines, and there is little evidence that the CBD has led to improved invasive species management at the global scale.

Non-native species that pose direct threats to animals or plants (cultivated or wild) are actively managed at the international level by the World Organization for Animal Health (OIE) and International Plant Protection Convention (IPPC), respectively. While these instruments have proven effective for restricting the spread of some invaders, they have most often been used to address diseases of livestock and pests of crops, with less attention paid to invasive species that cause primarily environmental harm [124]. Within the framework of the IPPC is the European and Mediterranean Plant Protection Convention which develops regional measures to prevent the spread of invasive plants and plant pests for its 50 member nations (i.e. more than just the EU nations). Its focus has also been largely on pests of agriculture.

Although the EU now has policies that address several region-wide environmental issues (e.g. climate change, pollution by chemicals), it has not yet created legislation to address the full range of invasive species and their pathways. Instead, there are several regimes and directives that address some invasive species or some pathways of introduction. We give two examples here. First, Council Regulation 708/2007 sets procedures and standards for aquaculture within the EU with the goal of reducing the risks that non-native fish, or the diseases they carry, will become established and invasive. Second, the Plant Health Regime addresses the introduction and spread of invasive plants and plant pests, but has been used primarily to address pests of agriculture. Plants that pose risks of environmental harm, although they may arrive through the same pathways, are generally not covered.

Although the two examples just given address important aspects of the invasive species problem, the general European policy framework remains spread across many similar and disjunct pieces of legislation. This creates confusion about which species and pathways should be addressed by which instrument, and ultimately means that many invasive species and pathways are not addressed [124]. In response, several programs have been established to identify gaps in the current framework and to suggest solutions. One example is the IMPASSE program that has reviewed the risks of introduction of invasive fish species and fish diseases through aquaculture (http://ec.europa.eu/research/fp6/ssp/impasse_en.htm). However, even if all recommendations from these programs were enacted, the basic European legislative framework would remain scattered, creating large obstacles to a coordinated response to the invasive species problem.

This lack of coordination has been identified as a serious shortcoming by the Commission of the European Communities [14]. In response, the commission set forth three policy options. The first is a business as usual model, in which the EU continues to rely on the current suite of national and EU policies, and the range of international policy instruments, to address invasive species. The second is to maximize use of the existing EU policy framework, possibly with some modifications of legal instruments so that they better address invasive species. This approach appeals because it would not require new legislation. However, it would still be limited in its application because no current policies address all invasive species or pathways. The final option is to create a new legal instrument at the EU level that would apply to all member states. This third option could be complemented by the creation of a European Centre for Invasive Species Management that would provide a coordinating role [125]

Shine et al [124] recently prepared a comprehensive review of existing national, international and European policy, and built upon this to evaluate the three policy options. They strongly recommended the final option a new legislative instrument - and noted that it is the only option that would provide a basis for coordinated action against all invasive species. Additionally, an economic analysis showed that although this option would 
be the most expensive, its costs would be much less than the avoided costs of the invasive species that it would prevent from arriving, or that would be managed more efficiently [124]. This recommendation is currently under consideration by the EU, and a final decision about policy approach is expected by 2012 .

\section{Conclusions}

Europe's position as a centre for international trade over many centuries has resulted in it having a large number and diversity of established non-native species. Many of these species are invasive and they affect all European habitats. Impacts include loss of native biodiversity, economic losses, and harm to human health. Over the last several decades the field of invasion biology has grown markedly [19] and has created a growing understanding of the biology of invasive species. One of the emergent insights of invasion biology has been that invasions are an inherently multi-disciplinary issue. More specifically, species are introduced through human economic activities. Without a clear understanding of these activities it is impossible to explain and understand biological invasions. This is clearly illustrated by the importance of propagule pressure as a driver of invasions. Propagule pressure is driven by human activities and is increasingly recognized as a strong factor in many, if not most, invasions.

Where timelines of species non-native species discovery are available, it is clear that the problem of invasions has not been fully addressed by current national or EU policies. Indeed, many European habitats appear to be acquiring new non-native species faster now than at any time in recorded history. Creating and enforcing policies that slow the rate of invasion is difficult for many reasons, including the value derived from many of the pathways that move the most species (e.g. shipping). These policies may be especially difficult in Europe because it is an environmentally heterogeneous region where barriers to the movement of goods have been actively removed to encourage free trade and travel. Despite this difficulty, current deliberations in the EU about developing a comprehensive policy instrument to address invasive species are very promising.

Apart from the policy and management considerations, the spread of non-native species offers many insights into biological and ecological processes as well as into the links between biodiversity, ecosystem functioning, and socio-economic impacts. Many researchers have been attracted to study species invasions because of the complexities, and the possibility to integrate across disciplines in ways that both generate new insight and that can lead to practical policy solutions. By reviewing a broad range of invasive species, and by reviewing both the biological and economic literature, we hope that this manuscript can make a useful contribution toward a more integrative understanding of species invasions in Europe.

\section{Acknowledgements}

We thank both the Alexander von Humboldt Foundation and the U. S. National Academy of Sciences for bringing us together at the $16^{\text {th }}$ GermanAmerican Frontiers of Science Symposium in Potsdam, Germany, June 2010. We especially thank Henner Hollert for inviting us to write this special review paper, and appreciate helpful comments by Ingo Kowarik and two anonymous reviewers. JMJ acknowledges financial support from the Deutsche Forschungsgemeinschaft (DFG; JE 288/4-1).

\section{Author details}

${ }^{1}$ Program on the Global Environment, University of Chicago, Chicago IL 60637, USA ${ }^{2}$ Aquatic Systems Biology Unit, Department of Ecology and Ecosystem Management, Technische Universität München, Mühlenweg 22, 85354 Freising, Germany ${ }^{3}$ Department of Biology II, Ludwig-MaximiliansUniversity Munich, Grosshaderner Str. 2, 82152 Planegg-Martinsried, Germany ${ }^{4}$ UFZ, Helmholtz Centre for Environmental Research-UFZ, Department of Community Ecology, Theodor-Lieser-Str. 4, 06120 Halle, Germany

\section{Authors' contributions}

RK, JG, JJ, and IK conceived of and designed this review paper. RK, JG, JJ, and IK each contributed research and draft text sections. RK organized all text into the final version. JG, JJ, and IK contributed equally. All authors read and approved the final manuscript.

\section{Competing interests}

The authors declare that they have no competing interests.

Received: 1 April 2011 Accepted: 20 June 2011 Published: 20 June 2011

\section{References}

1. Perrings C, Burgiel S, Lonsdale WM, Mooney $H$, Williamson M: International cooperation in the solution to trade-related invasive species risks. Ann NY Acad Sci 2010, 1195:198-212.

2. Kolar CS, Lodge DM: Progress in invasion biology: predicting invaders. Trends Ecol Evol 2001, 16:199-204.

3. Williamson M: Biological invasions London: Chapman \& Hall; 1996.

4. Sala OE, Chapin FS, Armesto JJ, Berlow E, Bloomfield J, Dirzo R, HuberSanwald E, Huenneke Lf, Jackson RB, Kinzig A, Leemans R, Lodge DM, Mooney HA, Oesterheld M, Poff NL, Sykes MT, Walker BH, Walker M, Wall DH: Global Biodiversity Scenarios for the Year 2100. Science 2000, 287:1770-1774.

5. Jeschke JM, Strayer DL: Invasion success of vertebrates in Europe and North America. P Natl Acad Sci USA 2005, 102:7198-7202.

6. DAISIE: Handbook of alien species in Europe. Dordrecht: Springer; 2009.

7. Vilà M, Basnou C, Pyšek P, Josefsson M, Genovesi P, Gollasch S, Nentwig W, Olenin S, Roques A, Roy D, Hulme PE, DAISIE partners: How well do we understand the impacts of alien species on ecosystem services? A panEuropean cross-taxa assessment. Front Ecol Environ 2010, 8:135-144.

8. Keller RP, zu Ermgassen PSE, Aldridge D: Vectors and timing of nonindignenous freshwater species establishment in Great Britain. Conserv Biol 2009, 23:1526-1534.

9. Hulme PE, Bacher S, Kenis M, Klotz S, Kühn I, Minchin D, Nentwig W, Olenin S, Panov V, Pergl J, Pyšek P, Roques A, Sol D, Solarz W, Vilà M: Grasping at the routes of biological invasions: a framework for integrating pathways into policy. J Appl Ecol 2008, 45:403-414.

10. Lambdon PW, Pyšek P, Basnou C, Hejda M, Arianoutsou M, Essl F, Jarosik V, Pergl J, Winter M, Anastasiu P, Andriopoulos P, Bazos I, Brundu G, CelestiGrapow L, Chassot P, Delipetrou P, Josefsson M, Kark S, Klotz S, Kokkoris Y, Kühn I, Marchante H, Perglova I, Pino J, Vilà M, Zikos A, Roy D, Hulme PE: Alien flora of Europe: species diversity, temporal trends, geographical patterns and research needs. Preslia 2008, 80:101-149.

11. Kowarik I: Biologische Invasionen: Neophyten und Neozoen in Mitteleuropa. 2 edition. Stuttgart: Ulmer; 2010.

12. Kowarik I: Time lags in biological invasions with regard to the success and failure of alien species. In Plant Invasions: General Aspects and Special 
Problems. Edited by: Pyšek P, Prach K, Rejmánek M, Wade M. Amsterdam: SPB Academic Publishing; 1995:15-38.

13. Essl F, Dullinger $S$, Rabitsch W, Hulme PE, Huelber K, Jarošík V, Kleinbauer I, Krausmann F, Kühn I, Nentwig W, Vilà M, Genovesi P, Gherardi F, DesprezLoustau ML, Roques A, Pyšek P: Socio-economic legacy yields an invasion debt. P Natl Acad Sci USA 2011, 108:203-207.

14. Commission of the European Communities: Towards a strategy on invasive species. 2008 [http://ec.europa.eu/environment/nature/ invasivealien/docs/1_EN_ACT_part1_v6.pdf], Communication from the Commission to the Council, the European Parliament, the European Economic and Social Committee and the Committee of Regions. COM (2008) 789 final.

15. Council of the European Union: A mid-term assessment of implementing the EU Biodiversity Action Plan and Towards an EU Strategy on Invasive Alien Species - Council conclusions. 2009 [http://register.consilium.europa. eu/pdf/en/09/st11/st11412.en09.pdf], Information Note 11412/09.

16. Lodge DM: Biological invasions: lessons for ecology. Trends Ecol Evol 1993, 8:133-137.

17. Sax DF, Stachowicz JJ, Brown JH, Bruno JF, Dawson MN, Gaines SD, Grosberg RK, Hastings A, Holt RD, Mayfield MM, O'Connor MI, Rice WR: Ecological and evolutionary insights from species invasions. Trends Ecol Evol 2007, 22:465-471.

18. Richardson DM, (ed): Fifty Years of Invasion Ecology - The Legacy of Charles Elton Chichester (UK): Wiley-Blackwell; 2011.

19. Richardson DM, Pyšek P, Rejmánek M, Barbour MG, Panetta FD, West CJ: Naturalization and invasion of alien plants: concepts and definitions. Divers Distrib 2000, 6:93-107.

20. Colautti Rl, Maclsaac HJ: A neutral terminology to define 'invasive' species. Divers Distrib 2004, 10:135-141.

21. Jeschke JM: Across islands and continents, mammals are more successful invaders than birds. Divers Distrib 2008, 14:913-916.

22. Thellung A: La flore adventice de Montpellier. Mémoires de la Société nationale des Sciences naturelles et mathématiques de Cherbourg 1912, 38:57-728.

23. Thellung A: Pflanzenwanderungen unter dem Einfluss des menschen. Beibl Bot jahrb Syst 1915, 53:37-66.

24. Wilson JRU, Dormontt EE, Prentis PJ, Lowe AJ, Richardson DM: Something in the way you move: dispersal pathways affect invasion success. Trends Ecol Evol 2009, 24:136-144.

25. Kowarik I, von der Lippe M: Pathways in plant invasions. In Biological Invasions. Edited by: Nentwig W. Berlin: Springer; 2007:29-47.

26. Holdich DM, Rogers WD, Reynolds JD: Native and alien crayfish in the British Isles. In Crayfish in Europe as alien species: how to make the best of a bad situation?. Edited by: Gherardi F, Holdich DM. Rotterdam: AA Balkema; 1999:221-235.

27. Benedict MQ, Levine RS, Hawley WA, Lounibos LP: Spread of the tiger: global risk of invasion by the mosquito Aedes albopictus. Vector-Borne Zoonot 2007, 7:76-85.

28. Keller RP, Drake JM, Drew M, Lodge DM: Linking environmental conditions and ship movements to estimate invasive species transport across the global shipping network. Divers Distrib 2011, 17:93-102.

29. Olenin S, Minchin D, Daunys D, Ziako A: Pathways of aquatic invasions in Europe. In Atlas of Biodiversity Risk. Edited by: Settele J, Penev LD, Georgiev TA, Grabaum R, Grobelnik V, Hammen V, Klotz S, Kotarac M, Kühn I. Sofia (Bulgaria): Pensoft; 2010:138-139.

30. Augustin S, Guichard S, Heitland W, Freise J, Svatoš A, Gilbert M: Monitoring and dispersal of the invading Gracillariidae Cameraria ohridella. J Appl Entomol 2009, 133:58-66.

31. Genovesi P, Bacher S, Kobelt M, Pascal M, Scalera R: Alien mammals of Europe. In Handbook of Alien Species in Europe. Edited by: DAISIE. Dordrecht: Springer; 2009:119-128.

32. Kark S, Solarz W, Chiron F, Clergeau P, Shirley S: Alien birds, amphibians and reptiles of Europe. In Handbook of Alien Species in Europe. Edited by: DAISIE. Dordrecht: Springer; 2009:105-118.

33. Roques A, Rabitsch W, Rasplus JY, Lopez-Vaamonde C, Nentwig W, Kenis M: Alien terrestrial invertebrates of Europe. In Handbook of Alien Species in Europe. Edited by: DAISIE. Dordrecht: Springer; 2009:63-79.

34. Pyšek P, Lambdon PW, Arianoutsou M, Kühn I, Pino J, Winter M: Alien vascular plants of Europe. In Handbook of Alien Species in Europe. Edited by: DAISIE. Dordrecht: Springer; 2009:43-61.

35. Bourke PMA: Emergence of potato blight, 1843-46. Nature 1964, 203:805-808.
36. Galil BS, Gollasch S, Minchin D, Olenin S: Alien marine biota of Europe. In Handbook of Alien Species in Europe. Edited by: DAISIE. Dordrecht: Springer; 2009:93-104

37. Gherardi F, Gollasch S, Minchin D, Olenin S, Panov VE: Alien invertebrates and fish in European inland waters. In Handbook of Alien Species in Europe. Edited by: DAISIE. Dordrecht: Springer; 2009:81-92.

38. Leuven RSEW, van der Velde G, Baijens I, Snijders J, van der Zwart C, Lenders HJR, bij de Vaate A: The river Rhine: a global highway for dispersal of aquatic invasive species. Biol Invasions 2009, 11:1989-2008.

39. Sol D, Vilà M, Kühn I: The comparative analysis of historical alien introductions. Biol Invasions 2008, 10:1119-1129.

40. Darwin C: On the Origin of Species by Means of Natural Selection, or the Preservation of Favoured Races in the Struggle for Life. London: Murray; 1859.

41. Cadotte MW: Darwin to Elton: early ecology and the problem of invasive species. In Conceptual Ecology and Invasion Biology: Reciprocal Approaches to Nature. Edited by: Cadotte MW, McMahon SM, Fukami T. Dordrecht: Springer; 2006:15-33.

42. Elton CS: The ecology of invasions by animals and plants. London: Methuen; 1958.

43. Levine JM, D'Antonio CM: Elton revisited: A review of evidence linking diversity and invasibility. Oikos 1999, 87:15-26.

44. Deutschewitz K, Lausch A, Kühn I, Klotz S: Native and alien plant species richness in relation to spatial heterogeneity on a regional scale in Germany. Global Ecol Biogeogr 2003, 12:299-311.

45. Stohlgren TJ, Barnett DT, Kartesz JT: The rich get richer: patterns of plant invasions in the United States. Front Ecol Environ 2003, 1:11-14.

46. Fridley JD, Stachowicz JJ, Naeem S, Sax DF, Seabloom EW, Smith MD, Stohlgren TJ, Tilman D, Von Holle B: The invasion paradox: Reconciling pattern and process in species invasions. Ecology 2007, 88:3-17.

47. Kühn I, Klotz S: From Ecosystem invasibility to local, regional and global patterns of invasive species. In Biological Invasions. Edited by: Nentwig W. Heidelberg: Springer; 2007:181-196.

48. Duncan RP, Blackburn TM, Sol D: The ecology of bird introductions. Annu Rev Ecol Evol S 2003, 34:71-98.

49. Leprieur F, Beauchard O, Blanchet S, Oberdorff T, Brosse S: Fish invasions in the world's river systems: when natural processes are blurred by human activities. PLOS Biol 2008, 6:e28, 2008.

50. Blackburn TM, Cassey P, Lockwood JL: The island biogeography of exotic bird species. Global Ecol Biogeogr 2008, 17:246-251.

51. Chiron F, Shirley S, Kark S: Human-related processes drive the richness of exotic birds in Europe. P Roy Soc B-Biol Sci 2009, 276:47-53.

52. Jeschke JM, Genovesi P: Do biodiversity and human impact influence the introduction or establishment of alien mammals? Oikos 2011, 120:57-64.

53. Kühn I, May R, Brandl R, Klotz S: Plant distribution patterns in Germany Will aliens match natives? Feddes Repertorium 2003, 114:559-573.

54. Pino J, Font $X$, Carbo J, Jove M, Pallares L: Large-scale correlates of alien plant invasion in Catalonia (NE of Spain). Biol Conserv 2005, 122:339-350.

55. Pyšek P, Kucera T, Jarosik V: Plant species richness of nature reserves: the interplay of area, climate and habitat in a central European landscape. Global Ecol Biogeogr 2002, 11:279-289.

56. Gasso N, Sol D, Pino J, Dana ED, Lloret F, Sanz-Elorza M, Sobrino E, Vilà M: Exploring species attributes and site characteristics to assess plant invasions in Spain. Divers Distrib 2009, 15:50-58.

57. Chytrý M, Pyšsek P, Wild J, Pino J, Maskell LC, Vilà M: European map of alien plant invasions based on the quantitative assessment across habitats. Divers Distrib 2009, 15:98-107, 2009.

58. Davis MA, Grime JP, Thompson K: Fluctuating resources in plant communities: a general theory of invasibility. J Ecol 2000, 88:528-534.

59. Britton-Simmons KH, Abbott KC: Short- and long-term effects of disturbance and propagule pressure on biological invasion. J Ecol 2008, 96:68-77.

60. di Castri F: History of biological invasions with special emphasis on the Old World. In Biological Invasions: A Global Perspective. Edited by: Drake JA, Mooney HA, di Castri F, Groves RH, Kruger FJ, Rejmánek M, Williamson M. Chichester UK: John Wiley and Sons; 1989:1-30.

61. Becker T, Dietz H, Billeter R, Buschmann H, Edwards PJ: Altitudinal distribution of alien plant species in the Swiss Alps. Perspect Plant Ecol 2005, 7:173-183.

62. Pyšek P, Jarošík V, Hulme PE, Kühn I, Wild J, Arianoutsou M, Bacher S, Chiron F, Didžiulis V, Essl F, Genovesi P, Gherardi F, Hejda M, Kark S, 
Lambdon PW, Desprez-Loustau ML, Nentwig W, Pergl J, Poboljšaj K, Rabitsch W, Roques A, Roy DB, Shirley S, Solarz W, Vilà M, Winter M: Disentangling the role of environmental and human pressures on biological invasions across Europe. P Natl Acad Sci USA 2010, 107:12157-12162.

63. Galil BS: A sea under siege - alien species in the Mediterranean. Biol Invasions 2000, 2:177-186.

64. Leppäkoski E, Olenin S, Gollasch S: The Baltic Sea: a field laboratory for invasion biology. In Invasive Aquatic Species of Europe: Distribution, Impacts and Management. Edited by: Leppäkoski E, Gollasch S, Olenin S. Dordrecht: Kluwer; 2002:253-259.

65. Panov VE, Bychenkov DE, Berezina NA, Maximov AA: Alien species introductions in the eastern Gulf of Finland: current state and possible management options. Proc Est Acad Sci Biol Ecol 2003, 52:254-267.

66. Panov V, Dgebuadze Y, Shiganova T, Filippov A, Minchin D: A risk assessment of biological invasions: inland waterways of Europe - the northern invasion corridor case study. In Biological Invaders in Inland Waters: Profiles, Distribution, and Threats. Edited by: Gherardi F. Dordrecht: Springer; 2007:639-656.

67. Wolff WJ, Reise K: Oyster imports as a vector for the introduction of alien species into northern and western European coastal waters. In Invasive Aquatic Species of Europe: Distribution, Impacts and Management. Edited by: Leppäkoski E, Gollasch S, Olenin S. Dordrecht: Kluwer; 2002:193-205.

68. Baker HG: The evolution of weeds. Annu Rev Ecol Syst 1974, 5:1-24.

69. Jeschke JM, Strayer DL: Determinants of vertebrate invasion success in Europe and North America. Global Change Biol 2006, 12:1608-1619.

70. Pyšek P, Richardson DM: Traits Associated with Invasiveness in Alien Plants: Where Do we Stand? In Biological Invasions. Edited by: Nentwig W. Dordrecht: Springer; 2007:97-125.

71. Genovesi P, Shine C: European strategy on invasive alien species. Strasbourg: Council of Europe Publishing; 2004.

72. Weber E, Köhler B, Gelpke G, Perrenoud A, Gigon A: Schlüssel zur Einteilung von Neophyten in der Schweiz in die Schwarze Liste oder die Watch-Liste. Bot Helv 2005, 115:169-194.

73. Gederaas L, Salvesen I, Viken Å: Norwegian Black List 2007: Ecological risk analysis of alien species. Trondheim: Artsdatabanken; 2007

74. Parrott D, Roy S, Baker R, Cannon R, Eyre D, Hill M, Wagner M, Preston C, Roy H, Beckmann B, Copp GH, Edmons N, Ellis J, Laing I, Britton R, Gozlan RE, Mumford J: Horizon scanning for new invasive non-native animal spe-cies in England. Sheffield: Natural England; 2009.

75. Nehring S, Essl F, Klingenstein F, Nowack C, Rabitsch W, Stöhr O, Wiesner C, Wolter C: Schwarze Liste invasiver Arten: Kriteriensystem und Schwarze Listen invasiver Fische für Deutschland und für Österreich. Bonn (Germany): Bundesamt für Naturschutz; 2010.

76. Keller RP, Drake JM: Trait based risk assessment for invasive species. In Bioeconomics of Invasive Species: Integrating Ecology, Economics, Policy and Management. Edited by: Keller RP, Lodge DM, Lewis MA, Shogren JF. New York: Oxford University Press; 2009:44-62.

77. Hayes KR, Barry SC: Are there any consistent predictors of invasion success? Biol Invasions 2008, 10:483-506.

78. Lockwood $J \mathrm{~L}$, Cassey $\mathrm{P}$, Blackburn $\mathrm{T}$ : The role of propagule pressure in explaining species invasions. Trends Ecol Evol 2005, 20:223-228.

79. Blackburn TM, Duncan RP: Establishment patterns of exotic birds are constrained by non-random patterns in introduction. J Biogeogr 2001, 28:927-939.

80. Sol D, Duncan RP, Blackburn TM, Cassey P, Lefebvre L: Big brains, enhanced cognition, and response of birds to novel environments. $P$ Natl Acad Sci USA 2005, 102:5460-5465.

81. Cassey P, Blackburn T, Russell GJ, Jones KE, Lockwood JL: Influences on the transport and establishment of exotic bird species: an analysis of the parrots (Psittaciformes) of the world. Global Change Biol 2004, 10:417-426.

82. Blackburn TM, Cassey P, Lockwood $J$ : The role of species traits in the establishment success of exotic birds. Global Change Biol 2009, 15:2852-2860

83. Hanspach J, Kühn I, Pyšek P, Boos E, Klotz S: Correlates of naturalization and occupancy of introduced ornamentals in Germany. Perspect Plant Ecol 2008, 10:241-250.

84. Williamson M, Dehnen-Schmutz K, Kühn I, Hill M, Klotz S, Milbau A, Stout J, Pyšek $P$ : The distribution of range sizes of native and alien plants in four European countries and the effects of residence time. Divers Distrib 2009, 15:158-166.
85. Pyšek P, Jarošik V, Pergl J, Randall R, Chytrý M, Kühn I, Tichy L, Danihelka J, Jun JC, Sádlo J: The global invasion success of Central European plants is related to distribution characteristics in their native range and species traits. Divers Distrib 2009, 15:891-903, 2009a.

86. van Kleunen $M$, Weber $\mathrm{E}$, Fischer M: A meta-analysis of trait differences between invasive and non-invasive plant species. Ecol Lett 2010, 13:235-245.

87. Dawson W, Fischer M, van Kleunen M: The maximum relative growth rate of common UK plant species is positively associated with their global invasiveness. Global Ecol Biogeogr 2011, 20:299-306.

88. Küster EC, Kühn I, Bruelheide H, Klotz S: Trait interactions help explain plant invasion success in the German flora. J Ecol 2008, 96:860-868.

89. Thompson K, Davis MA: Why research on traits of invasive plants tells us very little. Trends Ecol Evol 2011, 26:155-156.

90. Paavola $M$, Olenin S, Leppäkoski E: Are invasive species most successful in habitats of low native species richness across European brackish water seas? Estuar Coast Shelf S 2005, 64:738-750.

91. Strayer D, Downing JA, King TL, Layer JB, Newton TJ, Nichols SJ: Changing perspectives on pearly mussels, North America's most imperiled animals. BioScience 2004, 54:429-439.

92. Geist J: Strategies for the conservation of endangered freshwater pearl mussels (Margaritifera margaritifera L.): a synthesis of Conservation Genetics and Ecology. Hydrobiologia 2010, 644:69-88.

93. Keller RP, Drake JM, Lodge DM: Fecundity as a basis for risk assessment of nonindigenous freshwater molluscs. Conserv Biol 2007, 21:191-200.

94. Karatayev AY, Burlakova LE, Padilla DK, Matitsky SE, Olenin S: Invaders are not a random selection of species. Biol Invasions 2009, 11:2009-2019.

95. Strayer $\mathrm{DL}$, Eviner VT, Jeschke JM, Pace ML: Understanding the long-term effects of species invasions. Trends Ecol Evol 2006, 21:645-651.

96. Bisby FA, Roskov YR, Orrell TM, Nicolson D, Paglinawan LE, Bailly N, Kirk PM, Bourgoin T, Baillargeon G: Species 2000 \& ITIS Catalogue of Life: 2010 Annual Checklist.[http://www.catalogueoflife.org/annual-checklist/2010], Accessed 30 July 2010.

97. Pyšek P, Richardson DM, Rejmánek M, Webster BL, Williamson M, Kirschner J: Alien plants in checklists and floras: towards better communication between taxonomists and ecologists. Taxon 2004, 53:131-143.

98. Gherardi F, Bertolino S, Bodon M, Casellato S, Cianfanelli S, Ferraguti M, Lori E, Mura G, Nocita A, Riccardi N, Rossetti G, Rota E, Scalera R, Zerunian S, Tricarico E: Animal xenodiversity in Italian inland waters: distribution, modes of arrival, and pathways. Biol Invasions 2008, 10:435-454.

99. Kettunen M, Genovesi P, Gollasch S, Pagad S, Starfinger U, ten Brink P, Shine C: Technical support to EU strategy on invasive alien species (IAS) - Assessment of the impacts of IAS in Europe and the EU. Brussels: Institute for European Environmental Policy; 2009.

100. Kumschick S, Nentwig W: Some alien birds have as severe an impact as the most effectual alien mammals in Europe. Biol Conserv 2010, 143:2757-2762.

101. Nentwig W, Kühnel E, Bacher S: A generic impact-scoring system applied to alien mammals in Europe. Conserv Biol 2010, 24:302-311.

102. Vilà M, Weber E, D'Antonio CM: Conservation implications of invasion by plant hybridization. Biol Invasions 2000, 2:207-217.

103. Pyšek P, Cock MJW, Nentwig W, Ravn HP, (Eds): Ecology and management of giant hogweed (Heracleum mantegazzianum). Wallingford (UK): CABI; 2007.

104. Reinhardt F, Herle M, Bastiansen F, Streit B: Ökonomische Folgen der Ausbreitung von gebietsfremden Organismen in Deutschland Berlin: Umweltbundesamt; 2003.

105. Andreu J, Vilà M, Hulme PE: An assessment of stakeholder perceptions and management of noxious alien plants in Spain. Environ Manage 2009, 43:1244-1255

106. Dudgeon D, Arthington AH, Gessner MO, Kawabata ZI, Knowler DJ, Lévêque C, Naiman RJ, Prieur-Richard AH, Soto D, Stiassny MLJ, Sullivan CA: Freshwater biodiversity: importance, threats, status and conservation challenges. Biol Rev 2006, 81:163-182.

107. Geist J: Integrative freshwater ecology and biodiversity conservation. Ecol Indic 2011.

108. Souty-Grosset C, Holdich DM, Noel PY, Reynolds JD, Haffner P, (Eds): Atlas of crayfish in Europe. Paris: Museum National d'Histoire Naturelle; 2006, Patrimonines Naturels 64. 
109. Söderbäck B: Replacement of the native crayfish Astacus astacus by the introduced species Pacifastacus leniusculus in a Swedish lake: possible causes and mechanisms. Freshwater Biol 1995, 33:291-304.

110. Söderhäll K, Cerenius L: The crayfish plague fungus: history and recent advances. Freshwater Crayfish 1999, 12:11-35.

111. Rahel FJ: Homogenization of freshwater faunas. Ann Rev Ecol Syst 2002, 33:291-315.

112. Longepierre S, Robert A, Levi F, Francour P: How an invasive alga species (Caulerpa taxifolia) induces changes in foraging strategies of the benthivorous fish Mullus surmuletus in coastal Mediterranean ecosystems. Biodivers Conserv 2005, 14:365-376.

113. Lodge DM, Williams S, Maclsaac H, Hayes K, Leung B, Loope L, Reichard S, Mack RN, Moyle PB, Smith M, Andow DA, Carlton JT, McMichael A: Biological invasions: recommendations for policy and management. Ecol Appl 2006, 16:2035-2054.

114. Keller RP, Lodge DM, Lewis M, Shogren J: Bioeconomics of Invasive Species: Integrating Ecology, Economics, Policy and Management New York: Oxford University Press; 2009.

115. Molnar JL, Gamboa RL, Revenga C, Spalding MD: Assessing the global threat of invasive species to marine biodiversity. Front Ecol Environ 2008, 6:485-492.

116. Ricciardi A: Patterns of invasion in the Laurentian Great Lakes in relation to changes in vector activity. Divers Distrib 2006, 12:425-433.

117. Carlton J: Predictions of the arrival of the zebra mussel in North America. Dreissena Polymorpha Information Review 1991, 2:1.

118. Finnoff D, Shogren JF, Leung B, Lodge D: Take a risk: preferring prevention over control of biological invaders. Ecol Econ 2007, 62:216-222.

119. IUCN: IUCN Guidelines for the Prevention of Biodiversity Loss Caused by Alien Invasive Species. Gland (Switzerland): International Union for the Conservation of Nature; 2000 [http://iucn.org].

120. Keller RP, Lodge DM, Finnoff DC: Risk assessment for invasive species produces net bioeconomic benefits. P Natl Acad Sci USA 2007, 104:203-207.

121. Miller C, Kettunen M, Shine C: Scope options for EU action on invasive alien species (IAS). Final report for the European Commission. Institute for European Environmental Policy (IEEP), Brussels, Belgium; 2006.

122. Leung B, Lodge DM, Finnoff D, Shogren JF, Lewis MA, Lamberti G: An ounce of prevention or a pound of cure: bioeconomic risk analysis of invasive species. P Roy Soc B-Biol Sci 2002, 269:2407-2413.

123. Keller RP, Frang K, Lodge DM: Preventing the spread of invasive species: intervention guided by ecological predictions leads to economic benefits. Conserv Biol 2008, 22:80-88.

124. Shine C, Kettunen M, Genovesi P, EssI F, Gollasch S, Rabitsch W, Scalera R, Starfinger U, ten Brink P: Assessment to support continued development of the EU Strategy to combat invasive alien species. Final Report for the European Commission. Institute for European Environmental Policy (IEEP), Brussels, Belgium; 2010.

125. Hulme PE, Pyšek P, Nentwig W, Vilà M: Will threat of biological invasions unite the European Union? Science 2009, 324:40-41.

126. Essl F, Lambdon P: Alien bryophytes and lichens of Europe. In Handbook of Alien Species in Europe. Edited by: DAISIE. Dordrecht: Springer; 2009:29-41.

127. Gozlan E, Andreou D, Asaeda T, Beyer K, Bouhadad R, Burnard D, Caiola N: Pan-continental invasion of Pseudorasbora parva: towards a better understanding of freshwater fish invasions. Fish Fish 2010, 11:315-340.

128. Bernauer $D$, Jansen $W$ : Recent invasions of alien macroinvertebrates and loss of native species in the upper Rhine river, Germany. Aquat Invasions 2006, 1:55-71.

129. Van der Velde G, Rajagopal S, Kelleher B: Ecological impact of crustacean invaders: general considerations and examples from the Rhine river. Crustacean Iss 2000, 12:3-33.

130. Pöckl M: Success of the invasive Ponto-Caspian amphipod Dikerogammarus villosus by life history traits and reproductive capacity. Biol Invasions 2009, 11:2021-2041.

131. Bij de Vaate A, Jazdzewski K: Geographical patterns in range extension of Ponto-Caspian macroinvertebrate species in Europe. Can J Fish Aquat Sci 2002, 59:1159-1174.

132. Van der Velde G, Platvoet D: Quagga mussels Dreissena rostiformis bugensis (Andrusov, 1897) in the Main River (Germany). Aquat Invasions 2007, 2:261-264.
133. Figuerola J, Green AJ: Dispersal of aquatic organisms by waterbirds: a review of past research and priorities for future studies. Freshwater Biol 2002, 47:483-494.

134. Hussner A, Van de Weyer K, Gross EM, Hilt S: Comments on increasing number and abundance of non-indigenous aquatic macrophyte species in Germany 2010, 50:519-526, Weed Res.

doi:10.1186/2190-4715-23-23

Cite this article as: Keller et al: Invasive species in Europe: ecology, status, and policy. Environmental Sciences Europe 2011 23:23.

\section{Submit your manuscript to a SpringerOpen ${ }^{\mathcal{O}}$ journal and benefit from:}

- Convenient online submission

- Rigorous peer review

- Immediate publication on acceptance

- Open access: articles freely available online

- High visibility within the field

- Retaining the copyright to your article

Submit your next manuscript at $\gg$ springeropen.com 